Article to be published in the June 1998 issue of the Journal of European Public Policy

\title{
THE END OF NATIONAL POLICY CONCERTATION? WESTERN EUROPE SINCE THE SINGLE EUROPEAN ACT
}

\section{Hugh Compston}

\author{
School of European Studies, University of Wales \\ PO Box 908, Cardiff CF1 3YQ, WALES \\ E-mail: Compston@Cardiff.AC.UK
}

\begin{abstract}
It is widely believed that policy concertation between states, employer organisations and trade unions is declining under the impact of liberalising trends caused by factors such as increased mobility of capital, intensified international competition, diversification of patterns of production, greater social heterogeneity, decreased economic sovereignty, a political drift to the right, European integration and recession. In this article this proposition is put to the test by examining the incidence and extent of national-level policy concertation in eleven West European countries during the decade following the passage of the Single European Act in 1985. It is found that rumours of the death of concertation are greatly exaggerated: there was no general decline in policy concertation during this period.
\end{abstract}

\section{KEY WORDS}

Concertation, corporatism, employers, social partnership, trade unions, Western Europe

\section{INTRODUCTION}

The 1990s, according to many observers, have seen the triumph of neo-liberalism: for a variety of reasons national economies in Western Europe and elsewhere are now governed more by market forces and less by state regulation or concertation with business and trade unions than in the 1970s or 1980s. According to this view the formation of public policy by concertation between states and organisations representing capital and labour is now dysfunctional and on the decline as we approach a 21st century in which all but a few economic decisions are left to market forces, the rest being taken by states acting independently of economic interests.

But is this true? Are business and unions now sidelined from the making of public policy? Or are reports of the demise of macro-level policy concertation premature if not wholly inaccurate? The aim of this article is to examine the incidence and extent of recent policy concertation in Western Europe in order to answer this question. After making quite clear what policy concertation means in this context, previous research on factors affecting the rise and fall of concertation is reviewed in order to draw out the implications of various theories for contemporary trends in policy concertation. This sets the stage for an examination of the incidence and extent of policy concertation in eleven West European countries in the decade following the passage of the Single European Act in 1985, which was a major step forward in the process of economic liberalisation in Western Europe. The article concludes by summarising the main trends in concertation during this period and discussing the implications of these findings. 


\section{CONCERTATION DEFINED}

The involvement of business and trade unions in the making of public policy at the macro level is often discussed in the context of (neo)corporatism. Because the term 'corporatism' has been used by different writers to mean rather different things, including what I mean by concertation, it is useful to approach the definition of concertation by clearly distinguishing it from corporatism.

In the article that inspired the modern renaissance of interest in the idea of corporatism, Philippe Schmitter defined it as:

... a system of interest representation in which the constituent elements are organized into a limited number of singular, compulsory, non-competitive, hierarchically ordered and functionally differentiated categories, recognised or licensed (if not created) by the state and granted a deliberate representational monopoly within their respective categories in exchange for observing certain controls on their selection of leaders and articulation of demands and supports (1979, p.13).

Although corporatism as defined here has implications for policy-making, it is a pattern of organisation rather than a mode of policy-making as such. Schmitter's collaborator Gerhard Lehmbruch, however, defined corporatism not as a system of interest representation but as:

an institutionalized pattern of policy-formation in which large interest organizations cooperate with each other and with public authorities not only in the articulation ... of interests but ... in the 'authoritative allocation of values' and in the implementation of such policies (1979, p.150).

Given that the two definitions refer to two distinct albeit related types of phenomena, Schmitter suggested in the early 1980s that the term 'concertation' should be used to refer to the type of policy formation described by Lehmbruch so that the word 'corporatism' could be defined unambiguously as a system of interest intermediation (Schmitter 1982, p.263). It is this distinction that forms the basis of the definition of concertation used here, with the proviso that in order to focus directly on the vital political question of who decides public policy, the issue of policy implementation is left to one side.

Furthermore, the study takes an explicitly public policy perspective: the focus is on the way in which employers and trade unions are involved in the making of decisions that are ultimately the exclusive province of the state, in particular decisions on the contents of legislation, regulation and administrative orders. This is in contrast to what might be called an economic or industrial relations perspective, which concentrates primarily on the way in which the state becomes involved in decisions normally taken by employers and trade unions, such as wage-setting.

The object of attention, then, is national-level, inter-sectoral policy concertation at Cabinet level between government representatives and representatives of peak employer and/or trade union confederations about the formation of government policies relating to employment, prices, growth and trade. Potential areas covered, therefore, include fiscal policy, monetary policy, investment, industrial policy, trade policy, job-creation and training, employment law and social welfare.

Incomes policies are covered insofar as they include government commitments on economic policy, but their wage components are excluded because wage-setting is not the exclusive province of the state, apart from the wages of its own employees. In the private sector wages are ultimately the province of private employers. In this perspective collective bargaining can be regarded as a means by which trade unions participate in the decision-making of employers, and incomes policies, insofar as they relate to wages alone, can be viewed as means by which the state too becomes involved in the decision-making 
of employers, as opposed to being mechanisms through which employers and/or trade unions are involved in state decision-making. For this reason concertation over wage levels is considered to be a factor that influences policy concertation rather than a constituent part of policy concertation as such: an independent variable, rather than part of the dependent variable.

Within the realm of public policy defined above, the particular focus of interest is on discussions that lead to agreements on policy, that is, to government commitments to adopt particular economic policies, as opposed to discussions that do not lead to such commitments: codetermination of policy, as opposed to mere consultation. Attention is also paid to the scope of policy covered: concertation is considered to be more significant when there are agreements on a wide range of issues than when the subject matter is restricted.

To sum up, the focus of this study is on the incidence and extent of national policy concertation, defined as the codetermination of public policy by governments and employer groups and/or trade unions.

\section{CAUSES OF CONCERTATION}

The minimum condition for policy concertation to take place is the willingness of organised interests to negotiate and to compromise sufficiently to reach agreements. There are two main historical factors that have stimulated this willingness.

The first is the postwar extension of the role of the state. As the Keynesian state began to intervene more in the economy, in order to secure goals such as full employment and monetary stability for which it had become held responsible by the electorate, it became dependent on the cooperation of other economic actors for its policies to work. For this reason governments were prepared to concede influence in policy-making in order to obtain this cooperation. In this connection wage restraint was seen as particularly important. If inflation caused by excessive wage rises could be avoided, it was believed that both real wages and employment would benefit, and during the 1970s in particular agreements were reached in a number of West European countries whereby wage restraint was exchanged for concessions on non-wage elements of income, such as taxation and transfer payments (Lehmbruch 1979, pp.153-4; 1982, p.26; 1984, pp.64, 73). Streeck argues that the rise of concertation was in large part a reaction to the turmoil of 1968-9 and the economic problems beginning in 1973, and that it was an attempt to control inflation and unemployment simultaneously in countries with strong labour movements (1992, p.99-100). In other words, the opportunity for employer groups and trade unions to become involved in the public policy-making process - policy concertation - was exchanged for the opportunity for the state to influence wage levels: wage concertation.

The second factor facilitating the rise of policy concertation was the development of large and powerful interest groups, especially trade unions. There are two differing arguments as to why this is important. The first is that the rise of powerful trade union movements forces governments to negotiate with them on policy matters: the union power theory. The second is that the development of corporatist systems of interest intermediation - large, unified and centralised organisations representing employers and employees - has the consequence that the organisations involved can no longer externalise the economic costs of their actions. For example, if a trade union in a single industry makes excessive wage claims, it may be possible for the employers in that industry to pass these on in the form of higher prices to the rest of society, but if a union movement that encompasses most of a nation's workforce makes excessive wage claims, the resultant price rises hit everyone, including union members. For this reason an encompassing union movement would be expected to be more open to negotiating wage restraint (Olson 1982; Calmfors 1993). Corporatism also facilitates negotiations by limiting the number of participants, and gives to leaders of trade union confederations and employer peak associations the 
ability to make the binding commitments on behalf of their members that are essential if political exchange is to take place on a continuing basis. In the case of trade unions, for example, their leadership must be able to secure rank and file compliance with commitments on issues such as wage restraint if they are to be able to bargain effectively with business and government, and getting this compliance is likely to be easier for highly centralised national trade union confederations with few if any organisational rivals. Crouch suggests that this capacity to act strategically is enhanced by having within organisations strong vertical relations of interdependence both up and down, so that the leadership requires the consent of lower levels as well as having the power to make commitments on their behalf (Lehmbruch 1979, pp.167-8; Slomp 1992, p.163; Crouch 1993, pp.54-55, 289).

In addition to these two historical trends, a number of factors can be identified as being causes of intercountry differences in the incidence of concertation. First, it has been suggested that the greater prevalence of concertation in northern compared to southern Europe indicates that it is more likely to be established where the state is perceived as being reasonably neutral by both business and trade unions, rather than as an enemy (Hemerijck 1995; Slomp 1992, p.163). Historically, concertation has been associated with governments in which the working class has a voice via the party system, as these tend to give unions privileged access to state decision-making. Peter Katzenstein argues that economic openness facilitates the development of concertation because vulnerability to price competition for exports and from imports makes wage restraint especially important, thus providing a strong incentive for governments to offer trade unions and employers a role in policy-making in exchange for their cooperation. It has also been argued that concertation is facilitated by consociationalism, since political elites are already socialised into conflict management via top-level bargaining. Furthermore, a consensus among economists that concertation is valuable would obviously contribute to its legitimation. There is also the view that political culture is important, especially that of the labour movement: if norms of equality and solidarity are strong, for example, this may inhibit competition within the union movement over issues such as wage differentials and thereby make more likely compliance with incomes policies and therefore union involvement in the making of public policy (Lehmbruch 1979, pp.168-72; 1979a, p.304; 1984 pp.74-5; Katzenstein 1985).

A number of authors consider that organisational factors are important. Concertation is argued to be more stable when the partners participate in the implementation of policies through permanent interorganisational networks, on the grounds that this gives participants such high stakes in concertation that the option of exit becomes very costly. In addition, corporatist concertation at the national level is arguably facilitated by links between the state and organised interests at sectoral level, because these provide an institutional basis for widened forms of cooperation (Lehmbruch 1982, p.24; 1984, pp.634). Similarly, Crouch argues that generalised political exchange involving a dense web of exchanges between business, unions and government is more stable than single big exchanges such as social pacts, because success is not dependent on the outcome of a single set of negotiations (1993, pp.53, 62). Finally, concertation has been found to be more successful where top level horizontal networks cover several policy domains, since policies in one domain affect others (Scholten 1987, pp.28-30).

In summary, according to the political economy literature the main reasons for the development of policy concertation were the emergence of a willingness on the part of governments to trade policy concessions for certain commitments by employers and/or trade unions, and the development of corporatist systems of interest representation. Other important factors were labour party participation in government, economic openness, consociationalism, economic consensus, egalitarian political cultures, and the extensive institutionalisation of contacts between employers, trade unions and the state. 


\section{LIBERALISATION AND THE FUTURE OF CONCERTATION}

For policy concertation to come to an end, one or more of the participants must withdraw from the process of negotiating government policy. Scholars have identified two main recent developments in this regard: withdrawals by governments, for example the British Conservative government in 1979, and withdrawals by business peak organisations, for example the Swedish employer confederation SAF in the early 1990s. Although trade union confederations on occasion walk out of negotiations, there is little sign recently of union withdrawals from concertation as such.

A number of scholars have attributed the declining support of governments and business organisations for policy concertation to shifts in position caused by liberalising social and economic changes. These shifts can be grouped into three categories:

1. Business neo-liberalism: A shift in business preferences towards deregulation and decentralised bargaining due to increased competition and market instability stemming from internationalisation and the development of new technology, leading to pressures on firms to increase the diversity and flexibility of production, technology and social organisation (Lash and Urry 1987; Streeck 1992, pp.118-119; Hemerijck 1995, p.183). Windolf (1989) argues that as a result employers seek to create productivity coalitions between employers and workers by offering their employees greater job security and participation in strategic decision-making in exchange for cooperation with management and commitment to firm goals. In addition, the increased mobility of capital due to financial liberalisation is commonly recognised as making it less necessary for business to become involved in policy concertation in order to achieve its goals.

2. Government neo-liberalism: A shift in government economic policy from the late 1970s in the direction of market liberalism and deregulation due to a decline in the efficacy of national economic policy caused by increased economic interdependence, a shift to the Right in the composition of governments in a number of countries, and pressure from international monetary agencies and powerful international investors for deflationary policies. This made it difficult if not impossible to use fiscal or monetary measures to offer employment tradeoffs to trade unions in exchange for wage restraint, thus impeding successful concertation. At the same time higher unemployment lessened the perceived need for concertation by helping to bring down inflation. Declining economic sovereignty also led to a transfer of policy competences to the European Union in an effort to recover economic sovereignty at the European level, thus narrowing the scope of policy actually or potentially subject to national-level concertation. Finally, concertation was rendered less attractive for the government to the extent that it was made more difficult by business withdrawing its support (Lash and Urry 1987, p.234; Streeck 1992, pp.106-111; Crouch 1993, p.260; Hemerijck 1995, p.184).

3. Trade union weakness: A decline in the bargaining power of trade unions - their ability to reward governments and business for including them in policy-making, and to punish them if they are excluded - as a result of their declining ability effectively to represent employees due to the increasing heterogeneity of the workforce, which in turn is caused by the differentiation of social structures and collective interests that has resulted from technological progress and increasing education. Thus trade union alliances with social democratic parties were weakened by the emergence of a large and well-educated middle class and a broadening of the range of issues on the political agenda; new social movements such as the environmental and peace movements competed for the allegiance of union members; trade union unity was weakened by the decline of workingclass subcultures based on mass manufacturing; male trade union leaderships were challenged by the feminisation of the workforce; the emergence of large and growing service sector unions led to 
an erosion in the dominance of manual trade unions and especially of export industry unions, which have a greater interest in wage restraint and therefore concertation than more protected domesticbased unions; the development of large public sectors led to the emergence of militant trade unions opposed to the cuts in public services that export unions saw as necessary; and employers increasingly encouraged company unionism and the formation of productivity coalitions between individual employers and their workforces (Lash and Urry 1987, chapter 8; Streeck 1992, pp.118119; Hemerijck 1995, p.183; Windolf 1989; Crouch 1993, p.242).

The significance of these shifts is that the liberalising trends on which they are based are seen as irreversible, which implies a secular decline in the incidence and extent of policy concertation. Because the trends are general in nature rather than nation-specific, this decline would be expected to take place in all countries. The liberalisation hypothesis, then, is that in countries in which concertation previously existed, it is declining in incidence and/or the range of policy areas covered, and that where concertation is not already well-established, it will not develop.

\section{POLICY CONCERTATION SINCE THE SINGLE EUROPEAN ACT}

To test whether policy concertation is in fact declining in incidence and extent, the recent experience of eleven West European countries was examined, concentrating in particular on the decade since the passage of the Single European Act in December 1985. This date provides an appropriate symbolic starting point because it represents a distinct step forward both in the process of economic liberalisation and in the transfer of policy competences from the national to the supranational level, although it is the effect of liberalising trends in general that is the focus of interest rather than just those associated with the Single Market in particular. The eleven countries chosen constitute the great majority of rich West European industrial nations with long-established democratic polities, and in 1985 these countries together covered the full range of possibilities in relation to the incidence and extent of concertation:

1. Low concertation: Britain, France, Germany, Italy and Ireland. If the liberalisation hypothesis is correct, we should not find concertation emerging in these countries.

2. High concertation: Austria, Switzerland and Sweden. In these countries the liberalisation theory predicts a decline in the incidence and/or extent of policy concertation.

3. Intermediate cases: Denmark, Norway and the Netherlands. These are countries in which policy concertation was relatively low in 1985 despite long traditions of extensive concertation. The liberalisation hypothesis predicts a further decline in the incidence and/or extent of policy concertation.

\section{Low Concertation Countries in $\mathbf{1 9 8 5}$}

In Britain, little has changed in the decade since 1985: there has been no concertation on the macrolevel at all, and trade unions in particular have been excluded from taking any part in the policy process. Although a certain degree of concertation had taken place during the late 1970s during the period of the Social Contract, this was discredited by the Winter of Discontent in 1978-79 and terminated by the incoming Conservative government in 1979, and existing consultative mechanisms such as the National Economic Development were downgraded or abolished (Holliday 1993; Compston 1995b, pp.326-329). It remains to be seen whether the election of a Labour government in May 1997 will lead to any revival.

In France, too, where concertation has long been important in theory but rarely put into practice, little has changed since 1985. Despite the existence of formal channels through which concertation could take place, such as the Economic and Social Council, which gives advisory opinions on all Bills, these 
mechanisms have the reputation of being disconnected from the real policy process. Although concertation with large firms took place on a sectoral basis in the Modernisation Commissions of the Plans, Plans have declined in importance since the 1960s and are now of little relevance for government policy, although informal contact between the state and corporations continues to take place on a regular basis. During the first year or so of the Mitterrand government trade unions had an effective say in the policy process, but thereafter found themselves held at arms length until Gaullist Jacques Chirac became Prime Minister in 1986, when they were shut out of policy-making entirely. Since 1988 consultation has increased, with contacts with Ministers and civil servants being considered to be the most effective means of influencing policy, but no real concertation, in the sense of codetermination of policy, has taken place. A recent example of the French style of 'social dialogue' was the 'summit for employment' held in December 1995, after which the Juppé government issued conclusions despite their not having been signed by any of the employer organisations or trade union confederations present (Wilson 1993; Lash and Urry 1987, pp.262-269; Compston 1995b, pp.317-319; EIRR 1993, No.232; EIRR 1996, No.265, p.15).

Until reunification in 1990, levels of concertation in Germany were relatively low, but during the early 1990s a degree of concertation emerged briefly that is unparallelled in the postwar period in its explicit making of policy by consensus between the Federal government and not only employers and trade unions but also Land governments and the opposition Social Democrats (SPD). Interest groups have long been involved in (West) German national policy-making in a number of different ways, including via allied MPs in the Bundestag, links with political parties, and lobbying of the bureaucracy (Von Beyme 1993, pp.169-172), but there has been little if any formal co-determination of Federal policy. Despite the prominence of Concerted Action in the late 1960s and early 1970s, this was always a consultative forum rather than one at which government policy was hammered out, although of course the possibility of secret agreements and understandings cannot be ruled out. The same applies to the less formal 'bungalow' meetings held by SPD Chancellor Schmidt between 1977 and 1982. One reason for this avoidance of concertation is the opposition of employers and unions to government involvement in wage-setting, which renders concertation of less interest to the government. The Christian Democrat-Free Democrat government that succeeded Schmidt's in 1982 was even less interested in codetermining policy with employers and trade unions, although concertation continued to take place at the Land level (Compston 1995b, pp.323-326; Sally and Webber 1994). In response to the problems of German unification, however, in September 1992 Chancellor Kohl initiated and took part in separate but parallel negotiations with the Länder, the SPD, the trade unions (peak confederation DGB, IG Metall, IG Chemie and the public sector ÖTV), and business associations (insurance, banking, peak trade association BDI and the Chambers of Industry and Commerce), leading to the conclusion in March 1993 of the so-called Solidarity Pact. Although employer groups and trade unions were not formal signatories, the negotiations did lead to specific policy commitments by the government on aid to firms in the East, so that the Pact does represent policy concertation defined as codetermination of public policy. The motivation for the government was clearly that it needed the cooperation of business and unions in order to combat more effectively the East German crisis: the Solidarity Pact was an emergency measure involving specific policies rather than the introduction of a new routine way of making policy (Sally and Webber 1994; EIRR 1993, No.231). Nevertheless, it illustrates the point that where the incentives exist, even governments unsympathetic towards involving interest groups in policy-making may choose concertation as the best available option. And the conclusion in early 1996 of a tripartite agreement on unemployment, which dealt with issues such as early retirement, aid for business, pensions and vocational training, suggests that the Solidarity Pact of 1993 may not have been a one-off event (EIRR 1996 No.265, p.8; No.266, p.6). 
In Italy the incidence and extent of policy concertation increased between 1985 and 1996. Although historically interest groups have participated in policy-making mainly via relationships with particular government agencies (clientela) and parties (parentela) (Zariski 1993), in the decade or so after the 'hot autumn' of 1969 a number of bipartite or tripartite agreements were reached that included specific policy commitments on the part of the government, the broadest of which were the social pacts of 1977 and 1983. This period ended in 1984, when a split in the union movement over acceptance of another social pact led to a breakdown of national-level policy concertation. Towards the end of the decade agreements were reached on a more restricted range of economic and social issues, in particular the tax agreement of 1989, and the somewhat broader tripartite agreement of 1991 included provisions on state-controlled prices, employer contributions, and regional policy, but concertation on a wide range of government policy did not resume until July 1993 in the midst of the seismic system shift in Italy, when a tripartite Social Pact was signed in which the government made commitments on employment, taxation, education and training, health, housing and the labour market. This agreement also further rationalised industrial relations and contained a provision for two consultative meetings per year on economic policy along the lines of the German Concerted Action of the 1970s. In 1994 the conservative Berlusconi government was forced to sign an agreement with the trade unions on pension reform, having failed unilaterally to impose one, and a more far-reaching agreement on pensions was reached with the technocratic Dini government in May 1995 (Compston 1995b, pp.319-322; ILO 1995, pp.408-409; EIRR 1992, No.216, p.15; 1993, No.236, pp.15-19; 1996 No.264, pp.31-34; Regini and Regalia 1997). In September 1996, following the election of a centre-left government earlier in the same year, a tripartite employment pact was signed which included provisions on vocational training and education, labour market reform, and development in the South (EIRR 1996 No.275, pp.17-19). In summary, since 1985 there has been a significant increase in the importance of policy concertation in Italy, and by 1996 it was more stable and wider in scope than ever before.

In Ireland the period since 1987 has seen an unbroken series of broad social pacts based around incomes policy agreements. Although employers and trade unions only started to become institutionally involved in policy-making from the late 1950s, and the tripartite advisory National Economic and Social Council dates only from 1973, by 1980 they were involved in a wide range of public sector bodies. More importantly, after 1975 policy concessions were traded by the government for union agreement on wage restraint, leading up to the two National Understandings for Economic and Social Development in 1979 and 1980, which addressed tax, education, health, social welfare and conditions of employment. Although this practice was discontinued under the 1981-87 Fine GaelLabour government, since the return of Fianna Fail to power in 1987 economic policy has been based on a series of broad three-year tripartite agreements that included government commitments on public policy as well as provisions on wages: the Programme for National Recovery in 1987, which covered tax, social welfare, health, education, housing, employment and working time, and was widely considered to have been a big success; the Programme for Economic and Social Progress in 1990, which covered macroeconomic strategy, tax, social welfare, employment, and labour law; the Programme for Competitiveness and Work in February 1994, which covered tax and employment; and at the end of 1996, under the new Fine Gael-Labour government, Partnership 2000 for Inclusion, Employment and Competitiveness, which covered tax, industrial relations procedures and institutions, and employment (Compston 1994, pp.136-139; O'Kelly 1992; Hazelkorn and Patterson 1994, p.66; ILO 1995, pp.402-403; EIRR 1991, No.207, p.16; 1994 No.243, pp.14-16; 1997 No.277, pp.24-25). In other words, the years since 1985 have seen the zenith of policy concertation in Ireland.

To sum up, concertation remained low in two of the countries in which it had been low in 1985 Britain and France - but increased significantly in Germany, Italy and Ireland. 


\section{High Concertation Countries in $\mathbf{1 9 8 5}$}

In Austria policy concertation remains very important: although its scope has narrowed somewhat since 1985, there has been no significant decline. Ever since the 1950s Austria has been arguably the closest approximation to the ideal type of a corporatist country, with its system of compulsory functional Chambers plus a large and united trade union movement, and a very wide range of government policy was made by consensus between the social partners through the Parity Commission and other channels such as mandatory consultation on legislative proposals and representation on the Council of the Austrian National Bank and advisory bodies on taxation, trade and investment, as well as via allied members of Parliament (Fitzmaurice 1991, chapter 6; Compston 1994, pp.125-128). In the decade since 1985 it seems clear that although the range of policies subject to processes of concertation narrowed somewhat from the late 1970s, with price control dissolving due to import penetration, increasing disagreement between the social partners, and Parliament gaining power at the expense of the pre-parliamentary determination of policy by the social partners, nevertheless policy concertation remains important in such areas as economic policy and industrial relations, and social partnership still commands wide popular support. Furthermore, the institutional structure on which it is based remains in place despite some erosion of the solidity of its constituent organisations and increasing dissatisfaction with elements such as the emphasis on economic growth, the hierarchical and closed nature of the social partnership, and compulsory membership of the Chambers (Gerlich 1992; Crepaz 1994; Compston 1994, p.128; Traxler 1995).

The nature and extent of policy concertation in Switzerland remained essentially unchanged between 1985 and 1996. Due to the fact that only 50,000 signatures are needed to put recently-passed legislation to referendum, and a history that shows that legislation not supported by all important political and economic groups is generally defeated if a referendum is called, the Federal government has long needed to obtain general consensus on Bills before they go to the legislature in order to be assured of their ultimate implementation. The referendum threat, and hence the need for consensus policymaking, also exists at the cantonal level. Consensus at national level is obtained primarily through including representatives of business interests (especially the very powerful peak body Vorort), trade unions and other levels of government on the expert commissions that determine the overall shape of legislation. Interest groups also have access to the policy-making process through formal consultation (Vernehmlassungsfahren) and via allied MPs, and monetary policy is steered by agreements between the central bank and the big private banks. The scope of policy covered at the Federal level is rather narrower than in Austria due to Switzerland's decentralisation, and the Federal budget is not open to challenge by referendum, so concertation at the Federal level is limited mainly to tax, trade and labour market issues such as employment law and vocational training. Unlike EU Member States, however, policy competences have not been lost to the European level. Although recent economic difficulties have led to increased tensions in the policy-making process, the continued existence of the referendum mechanism has meant that for legislation to be successful it still needs broad support. This was demonstrated recently by the rejection at referendum of legislative measures to deregulate the labour market, which had been opposed by the trade unions, by a margin of two to one (Compston 1994, pp.128-130; Armingeon 1996; Steinberg 1996, p.106; Linder 1994, pp.118-130; EIRR 1997 No.276, p.13).

In contrast to Austria and Switzerland, the incidence and scope of concertation in Sweden has declined significantly since 1985. Sweden, with its large union movement and powerful employer federation SAF both integrated into the formal policy-making process and the boards of executive agencies, has long been considered one of the most corporatist countries in Western Europe, with a very high degree of concertation. Union and employer representatives were often appointed to government commissions 
of inquiry into new policy initiatives, which gave them considerable influence over policy proposals due to the expectation that reports would be unanimous. By law the government is obliged to consult affected interests on legislative proposals (remiss), and many members of the Riksdag are also members of interest groups, especially trade unions. Positions on the boards of executive agencies, such as the important Labour Market Board (AMS), gave interest group representatives a say in policymaking decisions within the ambit of the agency concerned. Finally, there was also considerable informal cooperation between the government and interest groups, especially between Social Democratic governments and the peak blue-collar union confederation LO. However since the 1970s things have changed. Following LO adoption in 1976 of the Meidner Plan to introduce wage-earner funds controlled by trade unions, which would have gradually transferred ownership of Swedish business to the union movement, relations between the LO and SAF deteriorated sharply. This trend was exacerbated when a change in SAF leadership resulted in a much more vigorously neo-liberal policy stance. One early indication of consequent problems was that it became more difficult to reach agreement in commissions, prompting the 1982-1991 Social Democratic government to reduce the number of commissions appointed, reduce the number of interest group representatives nominated to them, and insist on publication of reports even in the absence of unanimous agreement, thus effectively reducing the scope of codetermination of policy. In addition, the scope of policy agreed between the LO and Social Democratic governments, which previously had covered most areas of economic and social policy, narrowed during the 1980s. A further decline in policy concertation took place in 1991, when SAF unilaterally withdrew employer representatives from the boards of central agencies. Policy concertation in this form was terminated in 1992 when the new conservative-led government ousted all trade union representatives from executive boards. Bilateral concertation between the LO and Social Democrats resumed when the latter regained office in 1994, but since then relations have deteriorated, and the scope of policy codetermined by the LO and the government has narrowed even further (Elvander 1990; Petersson 1991; Ahrne and Clement 1992; Lewin 1994; Compston 1995a, pp.101-103; Micheletti 1995; Pestoff 1995; Pontusson and Swenson 1996). Sweden is one country in which concertation has definitely declined significantly since 1985 .

In short, since 1985 the incidence and extent of concertation has declined in Sweden but stayed high in Austria and Switzerland.

\section{Intermediate Cases}

Although national-level policy concertation was low in Denmark, Norway and the Netherlands at the end of 1985, their histories of high levels of concertation put them in a different category to the lowconcertation countries already surveyed. The liberalisation hypothesis predicts that policy concertation in these countries should not recover in the decade since 1985.

In Denmark, however, concertation has recovered significantly since its low point in the mid-1980s. Up to 1982 the pattern of interest group involvement in policy-making was similar to that of Sweden: membership of commissions and advisory committees, mandatory consultation on legislative proposals, consultation by Folketing committees, direct representation in the Folketing, and seats on the advisory Economic Council and on the boards of executive agencies. Incomes policy agreements provided an additional channel through which employers and trade unions could influence policy through exchanging wage restraint for government commitments on public policy. Furthermore, the peak blue-collar union confederation LO was able to codetermine much government policy through its very close links with the Social Democrats. Business was also involved in decision-making, although to a lesser extent. However it is clear that concertation was cut sharply in 1982, when the incoming conservative-led Schlüter government terminated codetermination of policy with the LO and kept the unions at arms length until the loss of a majority in the Folketing for its economic policy in 1987 
prompted renewed contacts. At the beginning of our period in 1985, then, concertation in Denmark was low despite the continued operation of the institutional mechanisms of consultation. This remained the case until 1993, when the Social Democrats returned to government and resumed substantive concertation with the LO. Although it appears that the area of agreement between the government and the LO on policy matters was narrower than in the period prior to 1982, it was nevertheless substantially higher than in 1985 (Buksti 1993; Miller 1993, pp.92-98, 128-137; Compston 1995a, pp.103-105).

In Norway the story is similar to Denmark: concertation was low in 1985 but has recovered since then and remains integral to the making of public policy. Concertation in Norway has historically taken a number of forms, including government commitments on public policy in the context of incomes policy agreements, the peak-level tripartite Contact Committee, the bipartite Labour-LO Cooperation Committee, formal consultation on bills both before and during the legislative process, and participation in committees attached to ministries. During most of the postwar period business and trade unions participated in the formation of a wide range of economic and social policy, but in 1981 the so-called 'blue wave' brought a conservative-led coalition to office that was unwilling to share decision-making power, so that by 1985 real concertation was low. With the return of a Labour government in 1986, however, concertation resumed, and since 1988 most economic policy has been decided by agreement between the government, the peak blue-collar union confederation LO and the peak employer group NHO, apart from the brief period of bourgeois government in 1989-90 (Compston 1995a, pp.106-109). On the other hand, the end of 'credit socialism' and the linking of the krone to the ecu narrowed the scope for macro-economic concertation, and it is clear that the links between Labour and the LO are loosening. Furthermore, in 1992 NHO briefly considered following the example of the Swedish SAF and leaving corporatist public bodies, but in the end decided to join the new tripartite Forum for the Creation of Values, a body designed to encourage industrial innovation and led by the Prime Minister (Dølvik and Stokland 1992, pp.162-164; Heidar 1994, p.107; Mjøset et al 1994, pp.71, 74). In 1993 the government, LO and NHO formulated the so-called 'Solidarity 2000' framework for economic policy, which included government commitments to a fixed exchange rate, continuation of active labour market programs at high levels, budget balance, increased government loans, and no changes to taxes or prices of government services (Karlsen 1996, p.151). Since 1985, then, the incidence and extent of policy concertation in Norway has risen, and continues at a high level on a wide range of issues.

Despite a complex network of bipartite and tripartite institutions set up in the postwar years, policy concertation in the Netherlands was at a low ebb by the mid-1980s, but since about 1989 there has been a resurgence in its importance. Up to about 1970 a high degree of consensus existed on economic policy, which meant that the recommendations of the tripartite Social and Economic Council tended to be accepted by the government. Since then, however, disagreement on economic policy has increased, and between 1982 and 1989 the centre-right Lubbers government bypassed the corporatist advisory channels, which meant that national-level policy concertation was low at the beginning of our period in 1985. Nevertheless, the institutional structure of consultation and concertation remained, and agreements on employment issues were reached in 1986 and 1987 between the government and the bipartite Foundation of Labour. In 1989, following the inclusion of Labour in the coalition government, the scope of concertation widened when agreement was reached on a broad economic and social policy framework, and although in 1990 the biannual 'spring and autumn' talks on economic and social issues came to an end, in November 1993 the tripartite 'New Course' agreement was reached in which wage restraint was traded for agreements on policies designed to avoid a resurgence of unemployment. In 1996 the government agreed to incorporate into law a bipartite agreement between employers and 
unions on conditions of employment, a form of concertation at a distance (Compston 1994, pp.130133; Hemerijck 1995, pp.197-221). In short, over the period 1985-1996 policy concertation became more, not less, important in the Netherlands.

To summarise, contrary to expectations the incidence and scope of policy concertation in Denmark, Norway and the Netherlands rose between 1985 and 1996.

\section{CONCLUSIONS}

Table 1 summarises developments in national-level policy concertation in the eleven countries surveyed.

Table 1. National-level Policy Concertation 1985-1996

1996

\begin{tabular}{|c|c|c|c|c|}
\hline & & $\begin{array}{l}\text { Significant } \\
\text { Decrease }\end{array}$ & $\begin{array}{c}\text { Little } \\
\text { Change }\end{array}$ & $\begin{array}{l}\text { Significant } \\
\text { Increase }\end{array}$ \\
\hline & Low & & $\begin{array}{l}\text { Britain } \\
\text { France }\end{array}$ & $\begin{array}{l}\text { Germany } \\
\text { Italy } \\
\text { Ireland }\end{array}$ \\
\hline 1985 & Intermediate & & & $\begin{array}{c}\text { Denmark } \\
\text { Norway } \\
\text { Netherlands }\end{array}$ \\
\hline & High & Sweden & $\begin{array}{c}\text { Austria } \\
\text { Switzerland }\end{array}$ & \\
\hline
\end{tabular}

This quite unequivocally refutes the hypothesis that during the period 1985-1996 liberalising trends in West European countries caused a significant general decline in the incidence and extent of nationallevel policy concertation in Western Europe. In six of the countries the level of concertation increased, and in four it remained essentially unchanged. Only in Sweden was there a significant decline.

Five main groups of countries can be distinguished. First, those in which regular concertation is the norm: Austria, Denmark, Norway, and the Netherlands. Second, Switzerland, where concertation is enforced by the existence of the referendum option on recently-passed legislation. Third, countries where there have been discrete social pacts: Germany, Ireland, and Italy. Fourth, Sweden, where some bilateral concertation still takes place between the LO and the Social Democratic government. Finally, countries in which concertation is low or non-existent: Britain and France.

Although concertation was not examined in depth for the West European countries not included in the above analysis - Spain, Portugal, Belgium, Luxembourg, Finland and Iceland - a superficial examination of these countries' recent histories reveals no reason to suspect that their inclusion would have significantly affected these results (ILO 1995, EIRR 1997, No.276, pp.32-33; 1996, No.267, pp.18-19).

Even compared to the high point of national policy concertation in the late 1970s there has been no general decline. Taking 1978 as a high-concertation starting point, levels of concertation in 1996 are significantly lower in only two of the eleven countries: Britain and Sweden. In France and Switzerland 
levels of concertation were very similar to those of 1978, while in Germany, Italy and Ireland they rose somewhat. In Austria, Denmark, Norway and the Netherlands the scope and/or incidence of concertation did fall to a certain extent, but it still remains relatively high. This means that there was a significant decline in only two countries out of eleven, which does not constitute a general trend.

The fact that policy concertation is not generally in decline does not mean that the trends on which the liberalisation hypothesis was based do not exist, but it does demonstrate that these liberalising trends have not (yet) had a significant influence. I therefore conclude this article by briefly canvassing the extent to which alternative theories can explain the above findings.

One view is that the effects of liberalising trends are overrated. For example, the argument that policy concertation has become more difficult due to a trend towards decentralised collective bargaining is undermined by recent findings that there is no general convergence of collective bargaining on a decentralised model (Traxler 1995a, pp.6-8; Wallerstein et al 1997). In addition, the persistence of policy concertation bears out the argument of Katzenstein (1985) that far from destroying concertation, economic openness stimulates it due to the perceived need to maximise competitiveness by enlisting the cooperation of business and trade unions in order to make the most of the few economic instruments still available to national governments.

A second alternative theory is that, in general, concertation varies cyclically according to cyclical factors, as opposed to being influenced by secular trends. Perhaps the most prominent such theory is that concertation rises under social democratic/labour governments and falls under conservative governments (Hemerijck 1995, p.183). Between 1985 and 1996 concertation in Denmark, Norway, Sweden and the Netherlands was obviously more frequent and extensive when labour parties were in government alone or in coalition than when they were in opposition. In Italy the advent of first technocratic and then centre-left governments was associated with a significant rise in concertation. However the partisan composition of government was not quite so helpful in explaining variations in policy concertation in other countries.

A third alternative theory is that contemporary economic trends are altering the content of concertation rather than destroying it. In support of this view it is argued that wage restraint remains important to national competitiveness, and that for EU member states it will become even more important if monetary union goes ahead because it will no longer be possible to devalue national currencies in order to retrieve a loss of competitiveness caused by excessive wage rises. Unless trade unions are destroyed altogether above the firm level, decentralised bargaining is likely in many cases to lead to leapfrogging rather than to wage restraint, which means that there is still a role for centralised incomes policy agreements in which wage restraint is exchanged for concertation on public policy even if many details about implementation on the employer/union side are decentralised to industry or firm level. Furthermore, since West European countries need to compete with newly industrialising countries on the basis of quality rather than labour costs, firms are required not only to be flexible but also to invest in capital goods, human capital, and research and development, and to build trust in relations with their workforces. This requires long-term planning and the provision of public goods such as a hardcurrency policy, training, and industrial policy, negotiations over which can form a basis for policy concertation. Traxler argues that where it already exists, concertation of this functionally well-adapted type is likely to remain, but considers that it is unlikely to develop where it is presently absent (Traxler 1995, pp.281-282; 1995a, pp.13-14 - see also Treu 1992, Rhodes 1997, Crouch 1993, pp.345-350; Slomp 1992, pp.168-172). The results of surveying policy concertation in recent years provides some evidence to support the view that there has been a shift in emphasis from macro- to micro-economic policy, as the most common policy areas in which concertation was important between 1985 and 1996 were those relating directly to the labour market: employment law, measures to reduce unemployment, 
and vocational training. Reforms to employment law often consisted of compromises between the desire of business and government for increased labour market flexibility and trade union concerns to protect job security and working conditions. On the other hand, concertation was still important in relation to taxation, pensions and other social welfare benefits, although the issue was often the reduction of costs rather than the expansion of programs. Macroeconomic strategy, monetary policy, national policy towards the European Union, aid for business, education, health, housing, and regional policy were less frequent objects of policy concertation.

A final possible explanation is that the incidence and extent of policy concertation is more heavily influenced by country-specific factors than by general social, economic and political trends. Crouch, for example, argues that the nature and extent of corporatist policy concertation depends mainly on individual state traditions, for example the relationship of organised groups to modernisation in previous centuries, the extent to which guild and functional chamber traditions carried over into the 20th century, and the power of labour parties in politics (1993, chapters 9-11). This implies that customary practices of policy concertation are likely to persist despite general international trends, and that the explanation for significant changes is to be found primarily in country-specific factors. Both of these propositions are consistent with our findings: concertation does seem to be 'sticky', with a tendency to return to past patterns even when changes occur (Denmark, Norway, Netherlands), and the dramatic developments in Germany, Italy and Sweden can be largely explained by unique countryspecific factors: the trauma of reunification in Germany, which required new solutions to new problems; the delegitimation of the regime in Italy during the early 1990s, which arguably made governments more prepared to trade policy concessions in exchange for the cooperation of business and trade unions; and the radicalisation of Swedish business in response to the attempt by the LO to force a transition to socialism via the introduction of wage-earner funds.

In this article the idea that national-level policy concertation is being eroded by contemporary liberalising economic and social trends has been tested and found wanting. Policy concertation is not generally in decline. In a number of countries its use is increasing. It is time to accept that concertation between business, trade unions and the state is here to stay as a major policy style in Western Europe. 


\section{ACKNOWLEDGEMENTS}

For their assistance in updating and checking the accuracy of my country accounts I would like to thank Klaus Armingeon, Nils Aarsaether, Ådne Cappelen, Mark Donovan, Elisabetta Gualmini, Niamh Hardiman, Thomas Koenig, Jill Lewis, Wolf Linder, Sue Milner, Nick Parsons, Victor Pestoff, Hans Slomp, Carsten Strøby Jensen, Douglas Webber, and Ulrich Widmaier. Responsibility for any errors remains mine alone. 


\section{REFERENCES}

Ahrne, Göran, and Wallace Clement (1992). 'A New Regime? Class Representation within the Swedish State', Economic and Industrial Democracy 13: 455-479.

Armingeon, Klaus (1996). 'Swiss Corporatism in Comparative Perspective', paper prepared for the conference on Globalization and the New Inequality, Utrecht, November 20-22.

Buksti, Jacob A. (1993). 'Interest Groups in Denmark', pp.100-112 in: Jeremy Richardson (ed.), Pressure Groups. Oxford: Oxford University Press.

Calmfors, Lars (1993). 'Centralisation of Wage Bargaining and Unemployment - A Survey', OECD Economic Studies 21: 161-191.

Compston, Hugh (1994). 'Union Participation in Economic Policy-Making in Austria, Switzerland, the Netherlands, Belgium and Ireland, 1970-1992', West European Politics 17: 123-145.

Compston, Hugh (1995a). 'Union Participation in Economic Policy-Making in Scandinavia, 19701992', West European Politics 18: 98-115.

Compston, Hugh (1995b). 'Union Participation in Economic Policy-Making in France, Italy, Germany and Britain, 1970-1993', West European Politics 18: 314-339.

Crepaz, Markus (1994). 'From Semisovereignty to Sovereignty: The Decline of Corporatism and the Rise of Parliament in Austria', Comparative Politics 27: 45-65.

Crouch, Colin (1993). Industrial Relations and the European State Tradition. Oxford: Clarendon Press.

Dølvik, Jon Erik, and Dag Stokland (1992). 'Norway: The 'Norwegian Model” in Transition', pp.143167 in: Anthony Ferner and Richard Hyman (eds.), Industrial Relations. Oxford: Blackwell.

EIRR - European Industrial Relations Review, various issues.

Elvander, Nils (1990). 'Incomes Policies in the Nordic Countries', International Labour Review 129(1): 1-21.

Fitzmaurice, John (1991). Austrian Politics and Society Today. London: Macmillan.

Gerlich, Peter (1992). 'A Farewell to Corporatism', West European Politics 15(1): 132-146.

Hazelkorn, Ellen, and Henry Patterson (1994). 'The New Politics of the Irish Republic', New Left Review 207: 49-71.

Heidar, Knut (1994), 'Towards Party Irrelevance? The Decline of Both Conflict and Cohesion in the Norwegian Labour Party', in: David S. Bell and Eric Shaw (eds.), Conflict and Cohesion in Western European Social Democratic Parties. London: Pinter.

Hemerijck, Anton C. (1995). 'Corporatist Immobility in the Netherlands', pp.183-226 in: Colin Crouch and Franz Traxler (eds.), Organized Industrial Relations in Europe: What Future? Aldershot: Avebury.

Holliday, Ian (1993). 'Organised Interests After Thatcher', pp.307-320 in: Patrick Dunleavy, Andrew Gamble, Ian Holliday and Gillian Peele (eds.), Developments in British Politics 4. London: Macmillan.

ILO (1995). 'Perspectives: Experience of Social Pacts in Western Europe', International Labour Review 134: 401-417.

Karlsen, Thore (1996). 'Norway', pp.146-167 in: The New Politics of Unemployment: Radical Policy Initiatives in Western Europe, ed. Hugh Compston. London: Routledge. 
Katzenstein, Peter (1985). Small States and World Markets. Ithaca, NY: Cornell University Press.

Lash, Scott, and John Urry (1987). The End of Organized Capitalism. London: Polity Press.

Lehmbruch, Gerhard (1979). 'Liberal Corporatism and Party Government', pp.147-183 in: Philippe C. Schmitter and Gerhard Lehmbruch (eds.), Trends Towards Corporatist Intermediation. London: Sage.

Lehmbruch, Gerhard (1979a), 'Concluding Remarks: Problems for Future Research on Corporatist Intermediation and Policy-Making', pp.299-309 in: Philippe C. Schmitter and Gerhard Lehmbruch (eds.), Trends Towards Corporatist Intermediation. London: Sage.

Lehmbruch, Gerhard (1982), 'Introduction: Neo-Corporatism in Comparative Perspective', pp.1-28 in: Gerhard Lehmbruch and Philippe C. Schmitter (eds.), Patterns of Corporatist Policy-Making. London: Sage.

Lehmbruch, Gerhard (1984). 'Concertation and the Structure of Corporatist Networks', pp.60-80 in: John H. Goldthorpe (ed.), Order and Conflict in Contemporary Capitalism. Oxford: Clarendon Press.

Lewin, Leif (1994). 'The Rise and Decline of Corporatism: The Case of Sweden', European Journal of Political Research 26: 59-79.

Linder, Wolf (1994). Swiss Democracy: Possible Solutions to Conflict in Multicultural Societies. Basingstoke and London: Macmillan.

Micheletti, Michelle (1995). Civil Society and State Relations in Sweden. Aldershot: Avebury.

Miller, Kenneth E. (1993). Denmark: A Troubled Welfare State. Boulder: Westview Press.

Mjøset, Lars, Ådne Cappelen, Jan Fagerberg and Bent Sofus Tranøy (1994). 'Norway: Changing the Model', pp.55-76 in: Perry Anderson and Patrick Camiller (eds.), Mapping the West European Left. London: Verso.

O'Kelly, Kevin P. (1992). 'Macro-economic Policies and Collective Bargaining in Ireland', pp.174180 in: Tiziano Treu (ed.), Participation in Public Policy-Making: The Role of Trade Unions and Employers' Associations. Berlin and New York: Walter de Gruyter.

Olson, Mancur (1982). The Rise and Decline of Nations. New Haven: Yale University Press.

Pestoff, Victor (1995). 'Towards a New Swedish Model of Collective Bargaining and Politics', pp.151182 in: Colin Crouch and Franz Traxler (eds.), Organized Industrial Relations in Europe: What Future? Aldershot: Avebury.

Petersson, Olof (1991). 'Democracy and Power in Sweden', Scandinavian Political Studies 14(2): 173191.

Pontusson, Jonas, and Peter Swenson (1996). 'Labor Markets, Production Strategies, and Wage Bargaining Institutions: The Swedish Employer Offensive in Comparative Perspective', Comparative Political Studies 29(2): 223-250.

Regini, Marino, and Ida Regalia (1997). 'Employers, Unions and the State: The Resurgence of Concertation in Italy?', West European Politics 20(1): 210-230.

Rhodes, Martin (1997). 'Globalisation, Labour Markets and Welfare States: A Future of "Competitive Corporatism"?', paper prepared for the Bern Joint Sessions of the European Consortium for Political Research.

Sally, Razeen, and Douglas Webber (1994). 'The German Solidarity Pact: A Case Study in the Politics of Unified Germany', West European Politics 3(1): 18-46. 
Schmitter, Philippe C. (1979). 'Still the Century of Corporatism?' pp.7-52 in: Philippe C. Schmitter and Gerhard Lehmbruch (eds.), Trends Towards Corporatist Intermediation. London: Sage.

Schmitter, Philippe C. (1982), 'Reflections on Where the Theory of Neo-Corporatism Has Gone and Where the Praxis of Neo-Corporatism May Be Going', pp.259-279 in: Gerhard Lehmbruch and Philippe C. Schmitter (eds.), Patterns of Corporatist Policy-Making. London: Sage.

Scholten, Ilja (1987), 'Introduction: Corporatist and Consociational Arrangements', pp.1-38 in: Ilja Scholten (ed.), Political Stability and Neo-Corporatism. London: Sage.

Slomp, Hans (1992). 'European Labor Relations and the Prospects of Tripartism', pp.159-173 in: Tiziano Treu (ed.), Participation in Public Policy-Making: The Role of Trade Unions and Employers' Associations. Berlin and New York: Walter de Gruyter.

Steinberg, Jonathan (1996). Why Switzerland? Cambridge: Cambridge University Press.

Streeck, Wolfgang (1992). 'From National Corporatism to Transnational Pluralism: European Interest Politics and the Single Market', pp.97-126 in: Tiziano Treu (ed.), Participation in Public PolicyMaking: The Role of Trade Unions and Employers' Associations. Berlin and New York: Walter de Gruyter.

Traxler, Franz (1995). 'From Demand-side to Supply-side Corporatism? Austria's Labour Relations and Public Policy', pp.271-286 in: Colin Crouch and Franz Traxler (eds.), Organized Industrial Relations in Europe: What Future? Aldershot: Avebury.

Traxler, Franz (1995a). 'Farewell to Labour Market Associations? Organized Versus Disorganized Decentralization as a Map for Industrial Relations', pp.3-19 in: Colin Crouch and Franz Traxler (eds.), Organized Industrial Relations in Europe: What Future? Aldershot: Avebury.

Treu, Tiziano (1992). 'Tripartite Social Policy-Making: An Overview', pp.1-25 in: Tiziano Treu (ed.), Participation in Public Policy-Making: The Role of Trade Unions and Employers' Associations. Berlin and New York: Walter de Gruyter.

Von Beyme, Klaus (1993). 'West Germany and the New Germany: Centralization, Expanding Pluralism, and New Challenges', pp.165-181 in: Clive S. Thomas (ed.), First World Interest Groups: A Comparative Perspective. Westport and London: Greenwood Press.

Wallerstein, Michael, Miriam Golden and Peter Lange (1997), 'Unions, Employers' Associations, and Wage-Setting Institutions in Northern and Central Europe, 1950-1992', Industrial and Labor Relations Review 50(3): 379-401.

Windolf, Paul (1989). 'Productivity Coalitions and the Future of European Corporatism', Industrial Relations 28(1): 1-20.

Wilson, Frank L. (1993). 'France: Group Politics in a Strong State', pp.113-125 in: Clive S. Thomas (ed.), First World Interest Groups: A Comparative Perspective. Westport and London: Greenwood Press.

Zariski, Raphael (1993). 'Italy: The Fragmentation of Power and Its Consequences', pp.127-138 in: Clive S. Thomas (ed.), First World Interest Groups: A Comparative Perspective. Westport and London: Greenwood Press. 